\title{
Druckfehler und Berichtigungen
}

für den XXXVI. Band der Monatshefte für Chemie (1915)

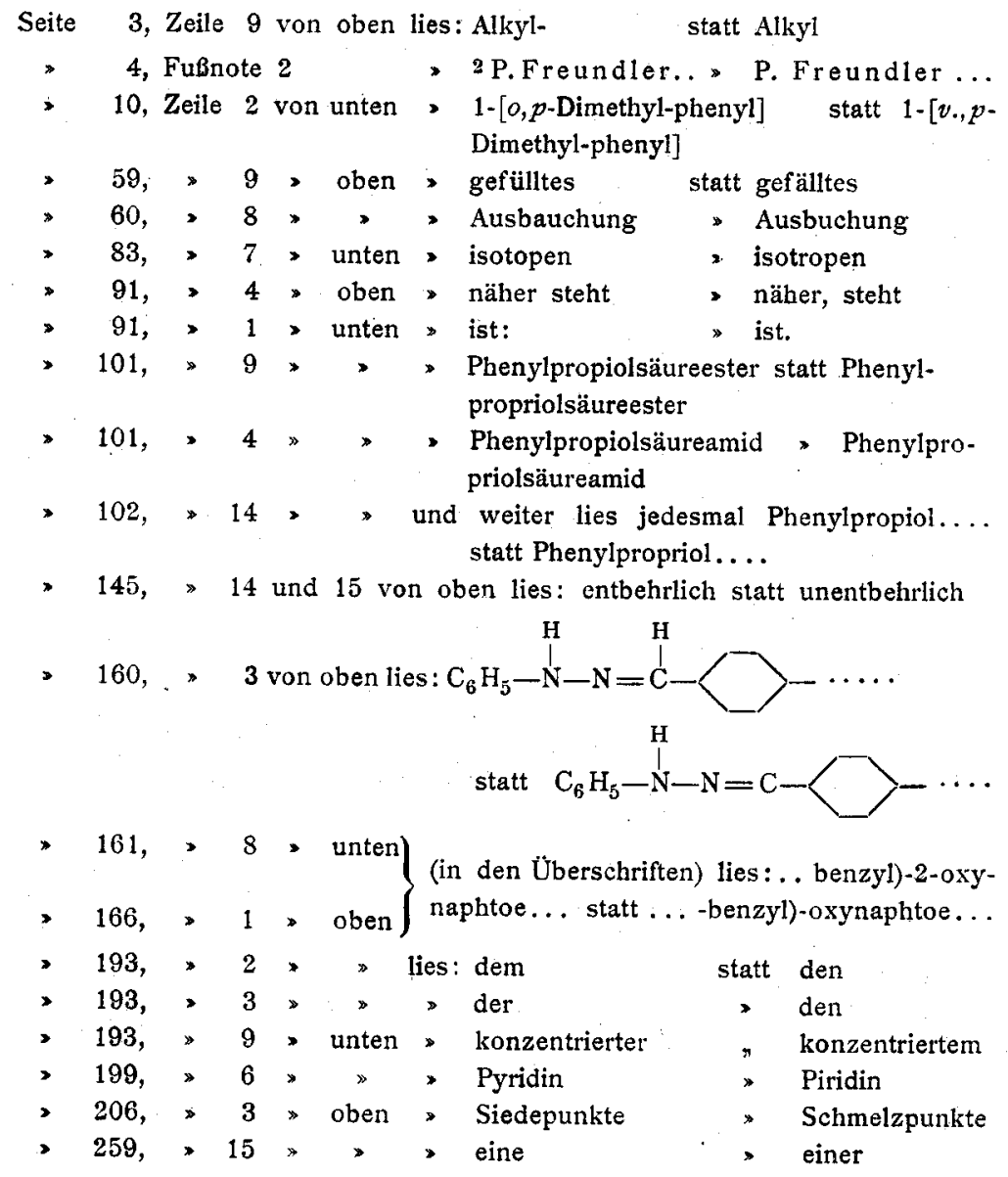




\section{VIEI}

Seite 318 , Zeile 2 von unten lies: röhren

statt löhren

> 362, $\gg 6$ oben $\$$ die

> 529, $3>$, Acetylsemicarbazid > Azetylsemi-

carbazid

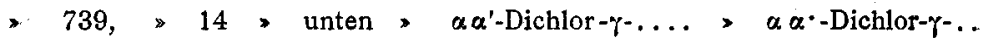

-924, $\gg 13>>$ in der Tabelle, Spalte 2 von rechts lies: $114 \cdot 5$

statt $134: 5$

$\gg \quad 929, \quad 7 \rightarrow$ oben lies: 29. April

28. April 